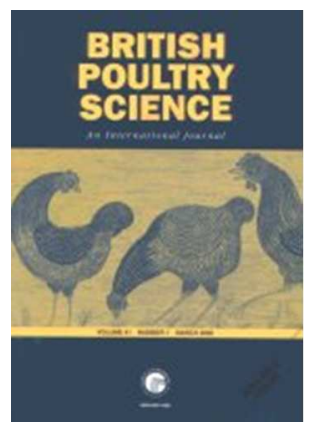

\title{
ABUSIVE USE OF ANTIBIOTICS IN POULTRY FARMING IN CAMEROON AND THEIR PUBLIC HEALTH IMPLICATIONS
}

\begin{tabular}{|r|l|}
\hline Journal: & British Poultry Science \\
\hline Manuscript ID & CBPS-2015-290.R1 \\
\hline Manuscript Type: & Original Manuscript \\
\hline Complete List of Authors: & $\begin{array}{l}\text { Guetiya Wadoum, Raoul Emeric; University of Dschang, Biochemistry; } \\
\text { University of Roma Tor Vergata, Biology; University of Camerino, } \\
\text { Comparative Morphology and Biochemistry } \\
\text { Zambou Ngoufack, Francois; University of Dschang, Biochemistry } \\
\text { Fonteh Anyangwe, Florence; University of Dschang, Animal Production } \\
\text { Njimou, Jacques Romain; University of Rome I "Sapienza", Chemical } \\
\text { Materials, Environmental Engineering } \\
\text { Coman, Maria Magdalena; University of Camerino, Comparative } \\
\text { Morphology and Biochemistry } \\
\text { Verdenelli, Maria Cristina; University of Camerino, Comparative Morphology } \\
\text { and Biochemistry } \\
\text { Cecchini, Cinzia; University of Camerino, Comparative Morphology and } \\
\text { Biochemistry } \\
\text { Silvi, Stefania; University of Camerino, Comparative Morphology and } \\
\text { Biochemistry } \\
\text { Carla, Orpianesi; University of Camerino, Comparative Morphology and } \\
\text { Biochemistry } \\
\text { Cresci, Alberto; University of Camerino, Comparative Morphology and } \\
\text { Biochemistry } \\
\text { Colizzi, Vittorio; University of Roma Tor Vergata, Biology }\end{array}$ \\
\hline \multirow{2}{*}{ Keywords: } & $\begin{array}{l}\text { Antibiotics Abuse, Antibiotics Residues, Maximum Residual Limit, Resistant } \\
\text { Pathogens, Foodborne Diseases, Public Health }\end{array}$ \\
\hline & \\
\hline & \\
\hline
\end{tabular}




\title{
ABUSIVE USE OF ANTIBIOTICS IN POULTRY FARMING IN CAMEROON AND THEIR PUBLIC HEALTH IMPLICATIONS
}

\author{
Guetiya Wadoum Raoul Emeric ${ }^{1,2,3 *}$ \\ ${ }^{1}$ Department of Biochemistry, Faculty of Sciences, University of Dschang, Cameroon \\ ${ }^{2}$ Department of Biology, University of Rome II "Tor Vergata Rome”, Italy \\ ${ }^{3}$ Department of Comparative Morphology and Biochemistry, University of Camerino, Italy \\ E-mail: raoulemeric@yahoo.fr; Tel: Cameroon: 00237-699898834; 00237-672478872; Italy: \\ 0039-3286658872; Sierra Leone: 00232-78425924; 00232-99520028; P.O. Box 67 Dschang, \\ Cameroon \\ Zambou Ngoufack François ${ }^{1}$ \\ ${ }^{1}$ Department of Biochemistry, Faculty of Sciences, University of Dschang, Cameroon \\ E-mail: Tel: 00237-677811129; P.O. Box 67 Dschang, Cameroon. \\ Fonteh Anyangwe Florence ${ }^{4}$ \\ ${ }^{4}$ Department of Animal Production, Faculty of Agronomy and Agricultural Sciences, University of \\ Dschang, Cameroon; E-mail: ; Tel: 00237-696818469; P.O. Box 96, Dschang, Cameroon
}

Njimou Jacques Romain ${ }^{5}$

${ }^{5}$ Department of Chemical Materials, Environmental Engineering, University of Rome I "Sapienza", Italy; E-mail: ; Tel: Italy: 0039-3204477178; Cameroon: 00237-675036570; P.O. Box 812, Yaounde, Cameroon

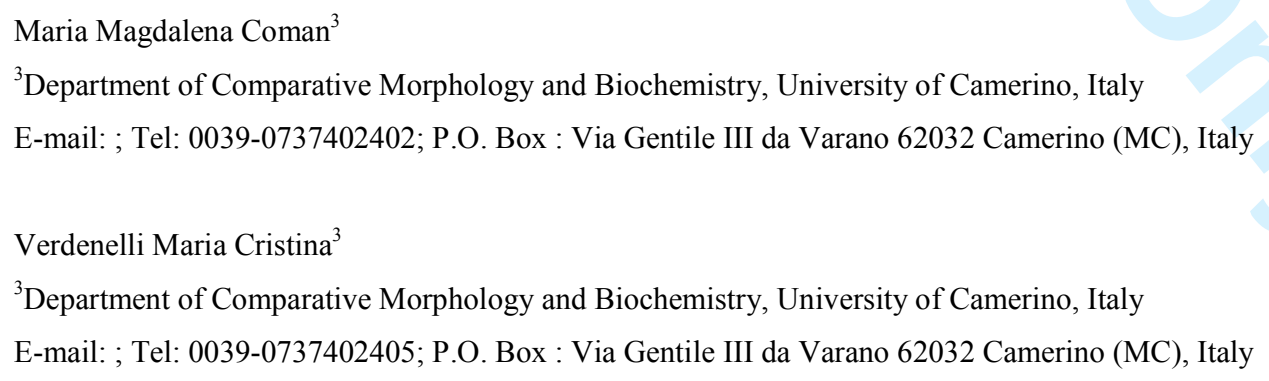


Cinzia Cecchini ${ }^{3}$

${ }^{3}$ Department of Comparative Morphology and Biochemistry, University of Camerino, Italy E-mail: ; Tel: 0039-0737-402405; P.O. Box : Via Gentile III da Varano 62032 Camerino (MC), Italy

\section{Stefania Silvi ${ }^{3}$}

${ }^{3}$ Department of Comparative Morphology and Biochemistry, University of Camerino, Italy

E-mail: ; Tel: 0039-0737-402405; P.O. Box : Via Gentile III da Varano 62032 Camerino (MC), Italy

\section{Orpianesi Carla ${ }^{3}$}

${ }^{3}$ Department of Comparative Morphology and Biochemistry, University of Camerino, Italy

E-mail: carla.orpianesi@unicam.it; Tel: 0039-0737402404; P.O. Box : Via Gentile III da Varano 62032 Camerino (MC), Italy

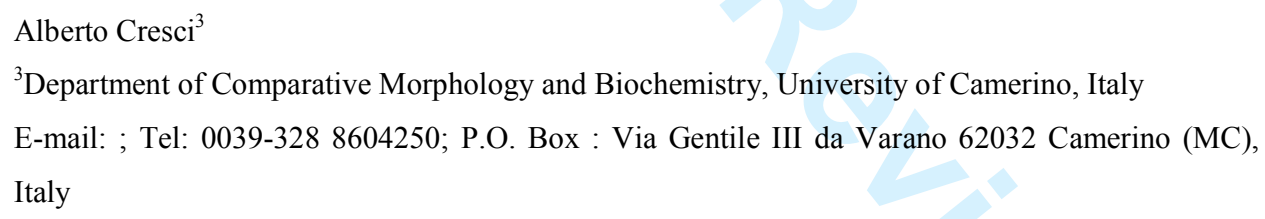

\section{*Corresponding author:}

Guetiya Wadoum Raoul Emeric, Laboratory of Biochemistry, Food Science and Nutrition (LABPMAN), Department of Biochemistry, Faculty of Science, University of Dschang, E-mail: raoulemeric@yahoo.fr; Tel: Cameroon: 00237-699898834; 00237-672478872; Italy: 00393286658872; Sierra Leone: 00232-78425924; 00232-99520028; P.O. Box 67 Dschang, Cameroon 


\section{ABSTRACT}

1 This study aimed to investigate the types and way of usages of antibiotics in poultry farms, their residual levels and the potential microbial resistances.

2 A questionnaire-based survey identified the different antibiotics used and High Performance Liquid Chromatography (HPLC) was used to determine antibiotics residual levels.

3 Pathogens were isolated, identified by use of API kits and Minimum inhibition Concentration (MIC) was determined.

4 Oxytetraxyclin, Tylocip and TCN were the most frequently used antibiotics. The antibiotics screened during HPLC were Chloramphenicol, Tetraxyclin and Vancomycin. All of them except Vancomycin were detected, and the concentration of these antibiotics was higher than the limit set by regulatory authorities Maximum Residual Limit (MRL).

5 However, no residues of various antibiotics were found in egg albumen or yolk. Furthermore, the concentration of Tetraxyclin was significantly high $(\mathrm{p}<0.05)$ in liver

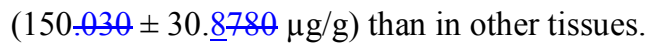

6 Foodborne pathogens including Salmonella sp., Staphylococcus sp., Listeria sp., Clostridium sp., and Escherichia species were identified. Most of the pathogens were resistant to various antibiotics tested.

7 These findings imply a better management of antibiotics to control sources of food contamination and reduce health risks associated with the presence of residues and the development of resistant pathogens.

$8 \mathrm{It}$ is suggested that relevant stakeholders like Veterinary Services, Food and Drugs Board, the Ministry of Livestock, Fisheries and Animal Industries, the Ministry of Public Health, Cameroon Poultry Farmers Association such as IPAVIC ("Interprofession Avicole du Cameroun") and consumers associations make advocacy for enacting and enforcing regulations on food hygiene and use of antibiotics. 


\section{INTRODUCTION}

The growth promoter effect of antibiotics was discovered in the 1940s, when it was observed that animals fed dried mycelia of Streptomyces aureofaciens containing chlortetracycline residues improved their growth. Their mechanism of action when used as growth promoters was early related to their interactions with intestinal microbial population (Dibner and Richards, 2005; Niewold, 2007).

Nowadays, the use of antibiotics as growth promoter in developing counties such as Cameroon has facilitated the efficient production of poultry allowing Cameroonians to purchase, at a reasonable cost, high quality meat and eggs. Although these uses benefit all involved, unfortunately, the edible poultry tissues may have harmful concentrations of drug residues.

In fact, antibiotics are substances either produced naturally by living organisms or produced synthetically in the laboratory, and they are able to kill or inhibit the growth of microorganisms. Also, they can be classified according to their effects as either bactericidal or bacteriostatic and according to their range of efficacy as narrow or broad in spectrum. Theirey use in animals shortly followed their use in humans for the purpose of disease prevention and treatment (Gustafsen, 1993). It have been also demonstrated that, the major antibiotics used for humans either belong to the same general classes or have the same mode of action as those used for animals (Joshi, 2002 Gelband et al., 2015).

Formatted: Font: Italic Today, antimicrobial drugs are used to control, prevent, and treat infection and to enhance animal growth and feed efficiency (Haihong et al., 2014Tollefson and Miller, 2000). Currently, approximately $80 \%$ of all food-producing animals receive medication for part or most of their lives. The most commonly used antimicrobials in food-producing animals are the $\beta$-lactams, tetracyclines, aminoglycosides, lincosamides, macrolides, pleuromutilins, and sulfonamides (De BriyneLee et al., 201401). Nevertheless, the use of these antibiotics in food-producing animals canmay leave residues in foodstuffs of animal origin like meat, milk, and eggs.

A chemical residue is either the parent compound or its metabolites that may deposit accumulate or otherwise be stored within the cells, tissues, organs or edible products of animals following its use to prevent, control or treat animal disease or to enhance 
production (Riviere and Sundlof, 2001). Antibiotic residues in foods from animal origin may be the cause of numerous health concerns in humans. They range from direct toxicity on consumers exhibiting allergy reactions, immunopathological diseases, carcinogenicity effects (e.g., sulphamethazine, Oxytetraxyclin, and furazolidone), mutagenicity, nephropathy (e.g., Gentamycin), hepatotoxicity, reproductive disorders, bone marrow toxicity (e.g., Chloramphenicol), allergy (e.g., penicillin) and the destruction of useful microflora present in the gastro-intestinal tract especially of children leading to indigestion (Nisha, 2008; Nonga et al., 2010); to indirect hazard through the generation of resistant strains of pathogenic bacteria which can be transfer to human and the residual contamination of manures used in crop productions (Dubois et al., 2001; Kaitlin, 2013). Grote et al. (2007) showed in model farming experiments that even plants can take up antibiotics from manure present in soil. This raised concern as antibiotic residues might be transferred into plants in amounts that could pose a health risk for consumers (BfRBundesinstitut für Risikobewertung, 2001).

These various health risks led to withdraw approval for antibiotics as growth promoters in the European Union since January 1, 2006. However, in other to ensure consumer safety, worldwide regulatory authorities have set MRL's (Maximum Residual Limit) for several veterinary drugs (European Union EEC, 1990;-Codex Alimentarius Commission CAC, 2012). These MRL's, are expected to regulate the maximum permitted levels of the drug residue for each antibiotic which is considered safely acceptable in food of animal origin (Woodward, 1993).

Moreover, the development of antimicrobial resistant bacteria strains of animal origin associated with antibiotic residues and its consequent effect on human health regarding the efficacy of antimicrobial therapy (Casadevall, 1996; Threlfall, 2002; Phillips et al., 2004) have become a worldwide public concern_(Akbar and Anal, 2014). According to Prescott and Baggot (1993), microbial resistance to antibiotics, particularly aminoglycosides (Streptomycin, Neomycin, and Kanamycin) is very common and pathogens present in foodstuffs of animal origin mainly S. aureus, E. coli O157:H7 and L. monocytogenes may easily develop antimicrobial resistance (Tanih et al., Griffin and Tauxe, 19912015). 
Therefore, monitoring antibiotics residues and the presence of pathogenic bacteria in animal derived food for human consumption has to be one of the most important duties for public health agencies (Samanidou et al., 2008). Despite this recommendation, there is no clear regulation for control of such residues and pathogens in animal products for human consumption in many African countries particularly in Cameroon.

The aim of this study was to investigate on the use of antibiotics by poultry farmers in one of Cameroon's important agro-pastoral region (Western Highlands), determine the residual levels of some antibiotics by High Performance Liquid Chromatography (HPLC) and establish the resistance profile of isolated pathogenic bacteria in other to demonstrate the public health hazards.

\section{MATERIALS AND METHODS}

\subsection{Localization of the study}

The study was conducted in the Western Highland of Cameroon which is an important agro-pastoral area of the country. The geographical references of the Western Highlands of Cameroon are latitude $5^{\circ} 20^{\prime}$ and $7^{\circ}$ North and longitude $9^{\circ} 40^{\prime}$ and $11^{\circ} 10^{\prime}$ East of the Equator (Nchinda and Mendi, 2008). This area includes two administrative Regions namely: the North-west Region with the town of Bamenda being the headquarters and the West Region with the town of Bafoussam as headquarters. Elevations reach as high as $3011 \mathrm{~m}$ and as low as $500 \mathrm{~m}$ above sea level, with the highest points being Mt. Bamboutos $2740 \mathrm{~m}$ in the West Region and Mt. Oku $3011 \mathrm{~m}$ in the North West Region. The climate is marked by a short dry season from November to mid March and a long rainy season from mid March to October. Rainfall ranges between 1300-3000 mm with a mean of $2000 \mathrm{~mm}$. Minimum and maximum temperatures have means of $15.50^{\circ} \mathrm{C}$ and $24.5^{\circ} \mathrm{C}$, respectively; although temperatures can go above $30^{\circ} \mathrm{C}$. Three types of soils exist in the western highlands: volcanic, hydromorphic and ferralitic soils. The human population is estimated at 1.82 million inhabitants, being one of the highest population densities in the country, with at least 79 inhabitants per $\mathrm{km}^{2}$ and a population growth rate of $3.1 \%$ (Nchinda and Mendi, 2008). This agro-pastoral area was purposively chosen, because he has the largest number of small and large scale poultry farms in Cameroon and contributing to about 56\% of poultry production in Cameroon (Ngatchou and Teleu, 2006; Keambou, 2013). 


\subsection{Questionnaire-Based Survey on Major Farms}

A Questionnaire-based survey in English and French was conducted on one hundred and thirty one (131) poultry farms to identify the most commonly used antibiotics, their dosage, timing of use and the practiced withholding times prior to dispatch. Between February and October 2012, several farms chosen randomly were contacted; only 131 agreed and participated between December 2012 and June 2013 to the survey. The georeference of each poultry farms was collected by the use of a Global Positioning System (GPS) receiver (GPSmap 76CSx, Garmin) and the softwares Google Earth, Global Mapper, Map Source and Adobe Illustrator CS4 were used to generate the map of the site.

\subsection{Public health hazard}

\subsubsection{Identification and quantification of antibiotic in edible tissues and eggs by HPLC}

\subsubsection{Ethics statement}

Animal experiments were performed according to the guidelines set for the care and use of laboratory animals and with the rules formulated under the Animal Welfare Act by the United States Department of Agriculture (USDA) and by adopting ARRIVE guidelines (Kilkenny et al., 2011).

\subsubsection{Preparation of samples}

Eighty five Chickens (35 Layers and 50 Broilers) were randomly collected in various poultry farms without prior information to the farmers, killed by section of the jugular vein and muscle, liver, heart, kidney and gizzards were sampled aseptically from each carcass. The randomization process was performed in laying Hen farms by selecting an equal number of animals in each corner of the pen without showing any preference while in broiler farms,$\div$ an equal number of animals were collected in each corner of the pen with consideration to have an equal amount of sex. FurthermoreAlse, 20 samples of each tissue were collected from commercial barbecued sale points. At the same time, eggs samples (35 
from poultry farms and 20 from commercial sale points) were randomly collected and placed in sterile polyethylene containers.

Prior to High Performance Liquid Chromatography (HPLC) analysis, a qualitative evaluation was performed through microbiological inhibition assay ("data not shown") as describe by Javadi et al. (2011), with the difference that the test organisms used were Bacillus cereus (ATCC 11778), Staphylococcus aureus (ATCC 25922) and Escherichia coli (ATCC 13706) and also due to the fact that samples supernatant were used rather than tissues. Positive samples were selected for HPLC analysis.

\subsubsection{Extraction and Quantitative Evaluation}

The positive samples obtained ( $\mathrm{T}=41: 5$ samples of each tissue, 8 albumen and 8 yolk) were dissolved in ultrapure water according to the ratio $0.3 \mathrm{~g}$ of sample in $10 \mathrm{~mL}$ and centrifuged at $2647 \mathrm{~g}$ for $10 \mathrm{~min}$. The supernatant was filtered through a $0.20 \mu \mathrm{m}$ cellulose acetate membrane filter (Schleicher \& Schuell, Roma, Italy) and used for analysis. A portion of $25 \mu \mathrm{l}$ of the filtrate was injected into the HPLC system for analysis. This analysis was performed on an Agilent Technologies 1200 HPLC system fitted with a SUPELCOSIL LC-18 column (length $250 \mathrm{~mm}$, diameter $4.6 \mathrm{~mm}$, packaging size $5 \mathrm{~mm}$, TK mediterranea $^{\mathrm{TM}}$ Sea 18, Roma, Italy) with ultra violet (UV) detector. The column temperature was settled to $20^{\circ} \mathrm{C}$. The mobile phase consists of an aqueous solution of $0.5 \%$ volume acetic acid ("A") and acetic nitrile ("B"). Elution was performed as follows: At the beginning and during the first 2 min of run, 100\% of "A"; from 2 min to 40 min after the beginning, a linear ramp was used, targeting $40 \%$ of " $\mathrm{A}$ " and $60 \%$ of "B". The flow rate was settled to $1 \mathrm{ml} / \mathrm{min}$ and antibiotics were detected by a UV detector $(280 \mathrm{~nm}$, TK mediterranea $^{\mathrm{TM}}$ Sea 18, Roma, Italy). Beforehand, the retention times of the interest antibiotics compounds (Tetraxyclin, Chloramphenicol and Vancomycin purchased from Oxoid) were measured by using single antibiotic standard solutions at a concentration of $100 \mathrm{mg} / \mathrm{l}$. These antibiotics were selected due to the high percentage of use by poultry farmers as reveal by the survey. The Detection Limit (DL) was defined as the concentration of antimicrobial that produces an analytical signal equal to thrice the standard deviation of the background signal and calculated as $8 \mathrm{ng} / \mathrm{g}$. 


\subsubsection{Susceptibility to antibiotics of isolated poultry pathogens}

\subsubsection{Isolation and Identification}

The collection of faeces was carried out on living birds localized at different geographical area according to the swab method as described by the International Organization for Animal Health (OIE) in the Terrestrial Manual (OIE, 2005). After sampling, pathogenic bacteria were isolated from 45 swab samples following the procedure describe by Aly et al. (2004). The selective growth media Manitol salt agar (Biolife ${ }^{\circledR}$, Milano, Italy), Listeria agar (Biolife $\AA$, Milano, Italy), Pseudomonas cetrimide agar (Oxoid, UK), Reinforce clostridia agar (Oxoid, UK) were used to isolate respectively Staphylococci sp., Listeria sp., Pseudomonas sp. and Clostridia species. Also, the semi-selective growth media Salmonella and Shigella agar (Merck, Darmstadt, Germany), XLD agar (Biolife ${ }^{\circledR}$, Milano, Italy) were used to isolate respectively Shigella sp., and Salmonella species. Finally, Mac Conkey agar (Conda, Madrid, Spain) was used to isolate other Enterobacteriaceae. All media and agar were prepared according to manufacturer's recommendations and were inoculated then incubated at $37^{\circ} \mathrm{C}$ for $24-48 \mathrm{~h}$. After incubation, colonies were examined for cultural and morphological properties on growth media. The selected isolates were identified by using API systems (API 20 E, API Staph and API 20 NE) galleries (Biomérieux, Marcy l'Etoile, France). Interpretations of the fermentation profiles were facilitated by systematically comparing all results obtained for the isolates studied with information from the computeraided database API LAB Plus V3.2.2. (). All cultures were maintained as stocks in specific broth at $-20^{\circ} \mathrm{C}$ with $15 \%$ glycerol.

\subsubsection{Determination of resistance profile of isolated pathogenic Bacteria}

The microdilution method was adopted and performed in a 96 wells microplate and MICs $(\mu \mathrm{g} / \mathrm{ml})$ were determined. The results of susceptibility status were interpreted according to the recent FEEDAP (Panel on Additives and Products or substances used in Animal Feed) document of the European Food Safety Authority (EFSA) on the update of the criteria used in the assessment of antibiotics bacterial resistance of human or veterinary importance (EFSA, 2008) and by the standards for antimicrobial disk and dilution susceptibility tests for bacteria isolated from animals approved by CLSI (Clinical Laboratory Standards 
Institute), formerly National Committee for Clinical Laboratory Standards (NCCLS, 2002). Strains showing MICs less than CLSI's breakpoints were considered sensitive; otherwise, they were resistant. The antibiotics including Ampicilin, Tetracyclin, Erythromycin, Amoxicillin-clavulanic acid, Chloramphenicol, Enrofloxacin, Gentamycin, Kanamycin, Vancomycin, Ceftiofur, and Trimethoprim-sulfamethoxazole obtained from Oxoid and Fluka were tested. The selection of these antibiotics was based on the CLSI's comprehensive list of antimicrobial agents that could be considered for routine testing by veterinary microbiology laboratories (National Committee for Clinical Laboratory StandardsNCCLS, 2002).

\subsection{Statistical Analyses}

The computer program GraphPad InStat version 3.10 was used for the one-way analysis of variance (ANOVA). Student-Newman Keels means comparison test were use at a statistical significance pre-set at $P<0.05$.

\section{Results and Discussion}

One hundred and thirty one (131) poultry farms were enrolled and participated in the present investigation. They were mainly large scale semi-intensive or intensive production units without inclusion of backyard production units. The questionnaire used in the present study was written in English and French since Cameroon is a bilingual country and also in consideration that the Western Highlands of Cameroon covers English and the French region. Furthermore, the investigators were bilingual, were coming from various tribe of the region and were able to explain the questionnaire to farmers through culture mediated channels. Between-Among the poultry farmsthem, $60.60 \%$ are localized in the West Region and $39.40 \%$ in the North West region (Figure). This proportion corroborate with the findings presented in the Food and Agriculture Organization (FAO) report establishing the aviculture situation in Cameroon (FAOSTAT, 2006).

Since the majority of farms managers and their farm hands had been generally formally educated, some with tertiary education and have had training in poultry production, they should be able to understand the necessity for enforcing farm hygiene and 
making informed decisions on choice, administration, storage and withdrawal periods of antibiotics upon veterinary advice and prescriptions (Table 1). However, is obvious that these farms managers didn't implement farm hygiene and good antibiotic management have concerngiven their education level.to implement farm hygiene and good antibiotic management. Similar findings on farm staff educational backgrounds and their implications have been described by Turkson (2008). Moreover, the finding that as much as $89 \%$ of the farm staff had never been medically examined before in relation to their jobs, gave the impression that they did not care for being possible agents for transmission of zoonotic diseases.

It is evident from-that majority of farmers constantly used antibiotics as prophylaxis and more intensively during disease outbreaks for treatments. Although minority of the farmers purchased medicines on prescription, it was noticeable that $80 \%$ of farmers, in spite of their formal education, made their own diagnosis and prognoses of diseases that were occurring or about to occur and formed their own opinions on what antibiotics to buy (Table 2). Liberalization of antibiotic imports in Cameroon has made antibiotics easily available (reference). It seemed that veterinary drug sellers did not insist on certified veterinary prescriptions before sales. They could even suggest the diagnoses of diseases to farmers so that they could sell their drugs. The situation could lead to unnecessary use and overuse of antibiotics, their wrong combinations, quick changeover to other drugs and improper dosage (Annan-Prah et al., 2012Khan, 1975). The result would be the production of antibiotic resistant strains of bacteria (Khachatourians, 1998) and cross resistance with other bacteria (Baker-Austin et al., 2006; World Health Organization, 20143).

From Table 3, it is apparent that the 26 drugs used in investigated farms could be grouped into antibiotics, formulations with low doses of antibiotics to be used as growth promoters, coccidiostats and-an-antihelminthic. Our results recorded that some of the antibiotics that were used neither gave information about their active ingredients nor their withdrawal periods. This usually occurred with imitated antibiotic products which could enter the country by unapproved routes to escape Veterinary Services, Food and Drugs Board and Standards Board's approval and customs duties (Annan-Prah et al., 2012). 
These results also indicate that Tylocip, TCN, Oxytetraxyclin and Amprolium powder were mostly used (Table 3). Tylosin is a macrolides antibiotic and the active ingredient of Tylocip. The soluble salt Tylosin tartrate is approved for poultry as a drinking water medication because Tylosin has a wide spectrum of activity against gram positive bacteria including Staphylococci and Streptococci, but narrow against gram negative bacteria like Campylobacter and Pasteurella multocida and against Mycoplasma gallisepticum, the causative agent of Chronic Respiratory Disease in poultry (Annan-Prah et al., 2012). However, resistance to Tylosin has been observed (ref). Cross-resistance to other members of the macrolides group has been reported especially to erythromycin, which is used extensively in human treatments (BAMBio Agri Mix, 2014). Although Tylosin is added to feed to promote increased rate of weight gain and improved feed efficiency, it is not approved for use as a feed medication for poultry in Canada and European countries (BAM, 2014; Phillips, 1999). It has been suggested that there are no or minimal benefits using antibiotics as growth promoters (Emborg et al., 2001; Engster et al., 2002; World Health OrganizationWHO, 20142003). Further, USDA (2009) asserts that the assumed economic and production benefits of antibiotics in animal feed can largely be improved by improved cleanliness of animal houses and improved testing for diseases. However, World Health OrganizationWHO (2000) advises that under no circumstances should antibiotics be used as an alternative to high-quality animal hygiene because overuse and abuse of antibiotics lead to the emergence of resistant strains in both the birds and man. The use of TNC powder presents two problems. The first is that it is a mixture of oxytetracycline, Chloramphenicol and Neomycin. The use of Chloramphenicol in veterinary medicine has been restricted to non-food animals (Annan-Prah et al., 2012). The United States has banned nitrofurans, Chloramphenicol and Ampicilin in animal feed. Germany and the Netherlands have forbidden penicillin and tetracycline in feed. Neomycin can worsen kidney disease in man (Wongtavatchai et al., 2004). The second issue is that TCN and Tylosin have withdrawal periods of 21 days and 10 days respectively, that makes it difficult for farmers who use them to wait for withdrawal periods before the sale of eggs or meat. Since $49.6 \%$ of investigated farms sold their products within the withdrawal periods, they is a high possibility for antibiotics residues to be present in these products reason while it is 
important to monitor the concentration of these residues in other to be sure that they do not exceed the MRL.

In order to assess the occurrence of antibiotics in chicken edible tissues and eggs, the HPLC method was used after preliminary qualitative microbiological screening ("data not shown"). HPLC was applied to quantitatively determine antibiotics residues in samples (Table 4). The antibiotics screened were Chloramphenicol, Tetraxyclin and Vancomycin. All the compounds except Vancomycin were detected, and the concentration of these antibiotics was higher than the limit set by regulatory authorities Maximum Residual Limit (EUEuropean ,Union, 2010). However, no residues of various antibiotics were found in egg albumen or yolk. This absence indicate that, the antimicrobial activities of selected eggs observed during preliminary qualitative microbiological screening maybe due to the presence of other antibiotics different from those use during HPLC. Kan and Petz (2000) had noted that drug residues will appear in both egg white and yolk after administration of drugs although poultry eggs contain a natural antibiotic substance, lysozyme, against most gram positive bacteria (Beuchat and Golden, 1989).

The levels of Tetraxyclin residues in all the tested samples were greater than the recommended MRL as set by the European Union (EU, 2010) regulation commission (Table 4). Furthermore, the concentration of Tetraxyclin was significantly high $(p<0.05)$ in liver $(150.030 \pm 30.8780 \mu \mathrm{g} / \mathrm{g})$ than in other tissues. This result may indicate that the application doses used by the investigated farmers are exceeding the recommendations or the farmers are not observing the withdrawal period. These findings are similar to that obtained in a study from Taiwan (Su-Ching et al.,2016) and come as confirmation of results presented earlier (Table 2) indicating that more than $49.6 \%$ of farmers sale their product within the withdrawal period. In addition, Chloramphenicol and Vancomycin is not approved for use as a medication for poultry in Canada and European countries (EUEuropean Union, 2009; BAMBio Agri Mix, 2014;-Phillips, 1999). Mohammad et al. (1997) suggest that among the factors responsible for the occurrence of antibiotic residues in food are: failure to observe withdrawal periods, extended usage or excessive dosages, poor records of treatment, off-label use of antibiotics, lack of consumer awareness of hazards of antibiotic residues in food and lack of enforcement of legislation. 
The unnecessary use of therapeutic doses of antibiotics or as growth promoters in producing animals may be a main cause for the selection of multiple resistant strains of bacterial pathogens which can result in serious human and animal infections (World Health Organization, 2014Barber et al., 2003). The microbiological analyses of swab samples from healthy chicken (Broilers and Layers) allowed in this study for the selection of the most common foodborne pathogens responsible of zoonoses diseases. These include among other Salmonella sp., Staphylococcus sp., Listeria sp., and Escherichia species (Table 5). Proietti et al. (2007) isolated salmonella strains in conventional broiler chickens gastrointestinal tract in central Italy. Neff et al. (2006) during a reference study on the prevalence of salmonella in flocks in Switzerland also isolated Salmonella strains. Furthermore, salmonella has been known to be the most prevalent pathogen to cause intramammary infections in poultry leading to major economic losses (Pengov et al., 2005) and Staphylococci may produce a heat stable toxin in contaminated meat, eggs or milk (Normanno et al., 2007). AnotherOther serious pathogens such as, Listeria was also isolated from samples. Listeria species have been linked with numerous outbreaks associated with animal derived products (Lyytikainen et al., 2000). Indeed, Proteus $s p$. are opportunistic diarrhea causes pathogens in poultry. Sambyal and Baxi (1980) had already detected occasional presence of bacteria of the genus Proteus in the digestive tract of chickens in Punjab in 1980. The other germs identified, namely Clostridium sp., are frequent cause of foodborne disease and are also associated with necrotic enteritis in chickens (Seyed et al., 2010). In addition, Pseudomonas aeruginosa infections are responsible of heavy losses in poultry farms. Furthermore, poor environmental sanitation noticed during the farms visits may be the cause of the presence of Shigella $s p$., Providencia rettgevi and Escherichia species in the analyzed samples. They are generally responsible of intestinal infections with more or less diarrhea. Recently, Tatsadjieu et al. (2009) isolated Salmonella choleraesuis, Salmonella arizonae, Citrobacter diverticus, Aeromonas salmonicida, Bordetella sp., Cedecea lapagei, Vibrio damsel, Proteus mirabilis and Pseudomonas cepacia in Broilers and Layers from poultry farms in North Cameroon (Ngaoundéré). 
Studies have shown that $E$. coli, a normal habitat of human and animal intestines, when constantly gets exposed to antibiotics; it develops resistance in order to survive. When these resistant isolates are excreted to the environment by faeces, they tend to spread resistance genes by vertical gene transfer to pathogens (Sorum and Sunde, 2001; Richard and Yitzhak, 2014). Thus, this will result in resistance to antimicrobial drugs used in treating infectious diseases leading to serious health implications in both humans and animals.

The above risks are reflected in the results that showed most of all isolated microorganisms from samples to be resistant to various classes of antibiotics tested (Table 6). Interestingly, when comparing the MIC values (in $\mu \mathrm{g} / \mathrm{ml}$ ) of the pathogenic isolates with CLSI's Minimal Inhibitory Concentration breakpoints for veterinary pathogens, we can clearly establish that these microorganisms are resistant. In fact, it is generally noticeable that most of the dangerous foodborne pathogens that are Listeria sp., Staphylococcus $s p$., Salmonella sp., Clostridium $s p$. and Escherichia species are resistant. $63.64 \%$ of all pathogens were resistant to Tetracycline, $45.46 \%$ to Kanamycin and $63.64 \%$ to Amoxicillin-clavulanic acid. Moreover, the resistance percentage for Ampicilin was $54.55 \%$, for Trimethoprim-sulfamethoxazole was $36.36 \%$ and $81.82 \%$ for Erythromycin. Finally, $45.46 \%$ of pathogens were resistant to Ceftiofur as well as $36.36 \%, 45.46 \%$, $54.56 \%$ and $63.64 \%$ of them were resistant respectively to Chloramphenicol, Enrofloxacin, Gentamycin and Vancomycin. Similar result was reported by Tatsadjieu et al. (2009) indicating that the bacteria identified, presented multiresistance to the 11 antibiotics tested. Also, our results are in agreement with investigations showing a high prevalence of multidrug-resistant bacteria in poultry carcasses (Abdel-Maksoud et al. 2015 Ojeniyi, 1989; Manie et al., 1998).

This may indicate that a high percentage of the chicken meat and eggs supply in Western Highlands market and in Cameroon in general may contain resistant strains of major foodborne pathogens against the mains drugs commonly used in therapeutic treatments; thus, incurring a major public health concern. Following the consumption of contaminated poultry meat or eggs, resistant bacterial strains may spread to the-human population, which will lead to the transfer of genes coding for resistance (Bogaard and Stobberingh, 2000; Olatoye et al., 2012; Richard and Yitzhak, 2014 ). The dissemination pathways of bacterial 


\section{RECOMMENDATIONS}

- Cameroon's veterinary sStakeholders must come together to enact guidelines regulatinggood farming practices the presence of antibiotic residues in food-and enforce them to promote hygiene compliance in poultry farms. 


\begin{abstract}
Furthermore, farmers should consult veterinarians and veterinary pharmacists or trained auxiliaries for a better advice on the type and quantity of antibiotics to be use as well as the respect of withdrawal period.

- Consumer associations should be more aware of the public health concern related to the presence of antibiotics residues in animal derived food and the generation of multiresistants pathogenic bacteria.

- Finally, the use of alternatives to antibiotics such as Probiotics, Prebiotics and Synbiotics as well as plant-derived antimicrobial substances and Charcoals may represent a promising option in the near future.
\end{abstract}

\title{
REFERENCE
}

Aly, S., Ouattara C.A.T., Savadogo, P.W., Ouattara A.S., Barro N. \& Traore, A.S. (2004) Microorganisms involved in Fulani traditional fermented milk in Burkina Faso. Pakistan Journal of Nutrition, 3: 134-139.

Annan-Prah, A., Agbemafle, E., Asare, P.T. \& Akorli, S.Y. (2012) Antibiotic use, Abuse and their Public Health Implication: The Contributory role of management Flaws in the Poultry Industry in two Agro-Ecological Zones in Ghana. Journal of Veterinary Advances, 2: 199208.

Baker-Austin, C., Wigth, M.S., Stepanauskas, R. \& McArthur, S.V. (2006) Co-selection of antibiotic and metal resistance. Trends in Microbiology, 14: 176-182.

BAM. (2014) HACCP Manual. Bio Agri Mix. Retrieved from http://www.bioagrimix.com/antimicrobial-resistance

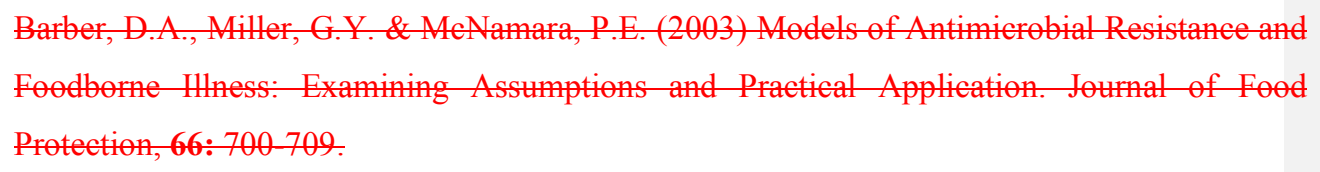


Beuchat, L.R. \& Golden D.A. (1989) Antibiotics occurring naturally in foods. Food Technology, 43: 134-142.

Bogaard, A.E. \& Stobberingh, E.E. (2000) Epidemiology of resistance to antibiotics. Links between animals and humans. International Journal of Antimicrobial Agents, 14: 327-335.

Bundesinstitut für Risikobewertung (BfR). (2011) Residue of pharmacologically active substances in plant-based food. BfR opinion No.051/2011, Available at: http://www.bfr.bund.de/en/publications.html.

Casadevall, A. (1996) Crisis in Infectious Diseases: Time for a New Paradigm?. Clinical Infectious Diseases, 23: 790-794.

Codex Alimentarius Commission. (2012) Maximum residue limits for veterinary drugs in foods. Updated as at the $35^{\text {th }}$ session of the Codex Alimentarius Commission. CAC/MRL 2: 140 .

De Briyne, N., Atkinson, J., Pokludová, L., Borriello, S. P. (2014) Antibiotics used most commonly to treat animals in Europe. Vet Rec. 175: 325.

Dibner, J.J. \& Richards, J.D. (2005) Antibiotic Growth Promoters in Agriculture: History and Mode of Action. Poultry Science, 84: 634-643.

Dubois, M., Fluchard, D., Sior, E. \& Delahaut, P.H. (2001) Identification and quantification of five macrolide antibiotics in several tissues, eggs and milk by liquid chromatographyelectrospray tandem mass spectrometry. Journal of Chromatography B: Biomedical Sciences and Applications, 753: 189-202.

EFSA. (2008) Technical guidance: Update of the criteria used in the assessment of bacterial resistance to antibiotics of human or veterinary importance. The EFSA Journal, 732: 1-15. 
Emborg, H., Ersboll, A.K., Heur, O.E. \& Wegener, H.C. (2001) The effect of discontinuing the use of Antibiotic growth promoters on the productivity of Danish broiler production. Preventive Veterinary Medicine, 50: 53-70.

Engster, H., Marvel, D. \& Steward-Brown, B. (2002) The effect of withdrawing growth promoters from broiler chicken: a long-term commercial industry study. The Journal of Applied Poultry Research, 11:431-436. doi: 10.1093/japr/11.4.431.

European Union. (2010) Commission regulation (EU) No 37/2010 of 22 December 2009 on pharmacologically active substances and their classification regarding maximum residue limits in foodstuffs of animal origin. Official Journal of the European Union Brussels, L15: $1-72$.

European Union. (2009) Regulation (EC) No 470/2009 of the European Parliament and the Council of 6 May 2009. Official Journal of the European Union, L152: 11-22.

FAOSTAT. (2006) Food and Agriculture Organization Statistics Databases. Available at: . Accessed March 2015.

Griffin, P.M. \& Tauxe, A.V. (1991) The epidemiology of infections caused by Escherichia coli O157:H7, other enterohemorrhagic $E$. coli and the associated hemolytic uremic syndrome. Epidemiologic Reviews, 13:60-98.

Gelband, H., Miller-Petrie, M., Pant, S., Gandra, G., Levinson, J., Barter, D., White, W., Laxminarayan, R. (2015) The State of the world's antibiotics, 2015. Centre for Disease Dynamics, Economics \& Policy, CDDEP: Washington, D.C 
Grote, M., Schwake-Anduschus, C., Michel, R., Stevens, H., Heyser, W., Langenkämper, G, Betsche, T. \& Freitag, M. (2007) Incorporation of veterinary antibiotics into crops from manured soil. Landbauforschung Völkenrode, 57: 25-32.

\section{Gustafson, R. (1993) Historical perspectives on regulatory issues of antimicrobial resistance.} Veterinary and Human Toxicology, 35: 2-5.

Haihong, H., Guyue, C., Zahid, I., Xiaohui, A., Hafiz, I., Hussain, L.H., Menghong, D., Yulian, W., Zhenli, L., Zonghui, Y. (2014) Benefits and risks of antimicrobial use in foodproducing animals. Front Microbiol. 5: 288. 10.3389/fmicb.2014.00288

Hummel, R., Tschäpe, H. \& Witte, W. (1996) Spread of plasmid-mediated nourseothricin resistance due to antibiotic use in animal husbandry. Journal of Basic Microbiology, 8: 461466.

Javadi, A., Mirzaie, H. \& Khatibi, S.A. (2011) Effect of roasting, boiling and microwaving cooking method on sulfadiazine + trimethoprim residues in edible tissues of broiler by microbial inhibition method. African Journal of Microbiology Research, 5: 96-99.

Joshi, S. (2002) HPLC separation of antibiotics present in formulated and unformulated samples. Journal of Pharmaceutical and Biomedical Analysis, 28: 795-809.

Kaitlin Tagg.2013. Human health, animal health, and ecosystems are interconnected. BMJ. 347: 44979

Kan, A.C. \& Petz, M. (2000) Residue of veterinary drugs in eggs and their distribution between yolk and white. Journal of Agricultural and Food Chemistry, 48: 6397-6403.

Keambou, T.C. (2013) The local fowl (Gallus gallus) of Cameroon: phenotypical, zootechnical and molecular diversity. Ph.D. Thesis, University of Dschang. 
Khachatourians, G.G. (1998) Agricultural use of Antibioties and the Evolution and Transfer of Antibiotic-Resistant Bacteria. Canadian Medical Association Journal, 159: 1129-1136.

\section{Khan, A.J. (1975) Misuse of antibiotics. In: Cento seminar on use and misuse of Antibiotic} drugs.

Kilkenny, C., Browne, W., Cuthill, I.C., Emerson, M. \& Altman, D.G. (2011) Animal research: reporting in vivo experiments the ARRIVE guidelines. Journal of Cerebral Blood Flow \& Metabolism, 31: 991-993.

Lee, H.J., Lee, M.H. \& Ruy, P.D. (2001) Public health risks: chemical and antibiotic residues. Asian-Australian Journal of Animal Science, 14: 402-413.

Levey, S.B., Fitzgerald, G.B. \& Macone, A.B. (1976) Spread of antibiotic resistance plasmids from chicken to chicken and from chicken to man. Nature, 260: 400-421.

Lyytikainen, O., Autio, T., Maijala, R., Ruutu, P., HonkanenBuzalski, T. \& Miettinen, M. (2000) An Outbreak of Listeria Monocytogenes Serotype $3 a$ Infections from Butter in Finland. Journal of Infectious Diseases, 181: 1838-1841.

Manie, T., Khan, S., Brozel, V.S., Veith, W.J. \& Gouws, P.A. (1998) Antimicrobial resistance of bacteria isolated from slaughtered and retail chickens in South Africa. Letters in Applied Microbiology, 26: 253-258.

Mohammad, G., Anal, A.K., Athur, M., Saleem, M. \& Bajracharya, S.I. (1997) Testing milk and meat for antibiotic residues. Pakistan Journal of food Science, 7: 35-38.

NCCLS. (2002) Performance Standards for Antimicrobial Disk and Dilution Susceptibility Tests for Bacteria Isolated from Animals; Approved Standard-Second Edition. NCCLS 
document M31-A2 [ISBN 1- 56238-461-9]. NCCLS, 940 West Valley Road, Suite 1400, Wayne, Pennsylvania 19087-1898, USA.

Nchinda, V.P. \& Mendi, S.D. (2008) Factors influencing the adoption of yoghurt technology in the Western Highlands Agroecological zone of Cameroon. Livestock Research for Rural Development, 20: 102. Accesed from .

Neff, C., Danuser, J. \& Hoop, R. (2006) Etude de référence sur la prévalence des salmonelles dans les cheptels de poules pondeuses de 1'espèce Gallus gallus. Rapport Final de l'Office vétérinaire Fédéral, 11.

Ngatchou, A. \& Teleu, N.E.T. (2006) Revue du secteur avicole au Cameroun. FAO, available at 54pp.ftp://ftp.fao.org/docrep/fao/011/ai356f/ai356f00.pdf.

Nicoline F., Tanih, Eunice Sekwadi, Roland N., Ndip, Pascal O., Bessong. (2015) Detection of Pathogenic Escherichia coli and Staphylococcus aureus from Cattle and Pigs Slaughtered in Abattoirs in Vhembe District, South Africa. The Scientific World Journal, 2015: 8. http://dx.doi.org/10.1155/2015/195972

Niewold, T. A. (2007) The nonantibiotic anti-inflammatory effect of antimicrobial growth promoters, the real mode of action? A hypothesis. Poultry Science, 86: 605-609.

Nisha, A. R. (2008) Antibiotics residues-A global health hazard. Veterinary World, 1: 375 377.

Nonga, H.E., Simon, C., Karimuribo, E.D. \& Mdegela, R.H. (2010) Assessment of antimicrobial usage and residues in commercial chicken eggs from small holder poultry keepers in Morogoro municipality, Tanzania. Zoonoses and Public Health, 57: 339-344. 
Normanno, G., La Salandra, G., Dambrosio, A., Quaglia, N.C., Corrente, M., Parisi, A., Santagada, G., Firinu, A., Crisetti, E. \& Celano, G.V. (2007) Occurrence, Characterization and antimicrobial resistance of enterotoxigenic Staphylococcus aureus isolated from meat and dairy products. International Journal of Food Microbiology, 115: 290-296.

OIE (Organisation Internationale des Epizooties). (2005) Chapitre 2.10.3 : Salmonelloses in : Formatted: French (France) Manuel terrestre de l'OIE. Rapport France, 1117-1133.

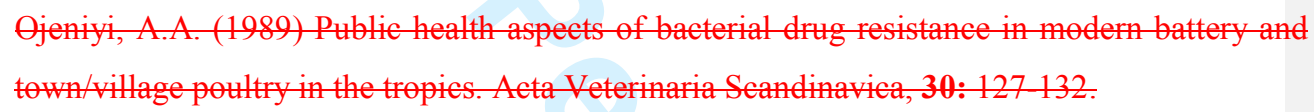

Olatoye, I.O., Amosun, E.A. \& Ogundipe, G.A.T. (2012) Multidrug Resistant Escherichia coli O157 Contamination of Beef and Chicken in Municipal Abattoirs of Southwest Nigeria Nature and Science, 10: 125-132.

Pengov, A., Flajs, C.V., Zadnik, T., Marinsek, J. \& Pogacnik, M. (2005). Distribution of Chloramphenicol Residues in Lactating Cows Following an External Application. Analytica Chimica Acta, 529: 347-351.

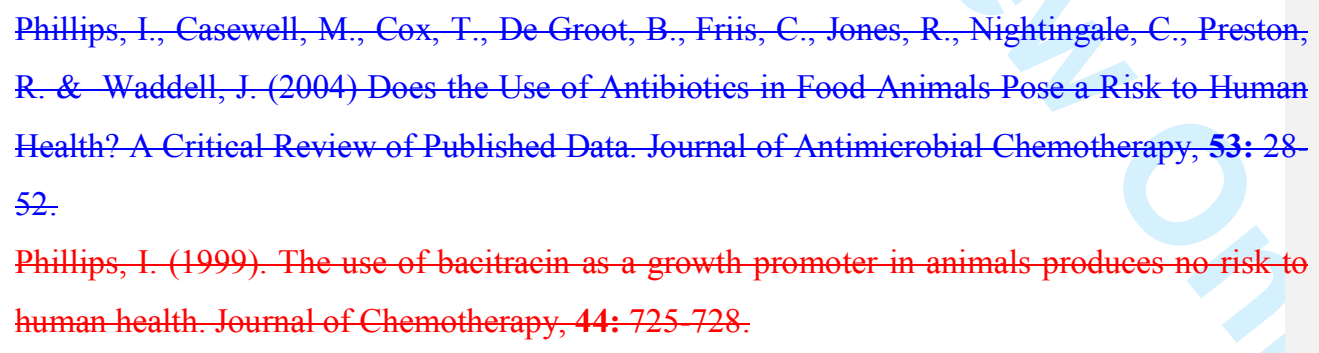

Prescott, J.F. \& Baggot, J.D. (1993) Antimicrobial Therapy in Veterinary Medicine. Iowa State University Press, Ames. 
Proietti, P.C., Castellini, C., Dal Bosco, A., Franciosini, P.M. \& Asdrubali, G. (2007) Investigation on intestinal bacterial flora and Salmonella spp. presence in organic and conventional chickens. Italian Journal of Animal Sciene, 6: 305-308.

Richard, J. F.,Yitzhak, T. (2014) Antibiotics and Bacterial Resistance in the 21st Century. $\underline{\text { Perspect Medicin Chem, 6: 25-64. Doi: 10.4137/PMC.S14459 }}$

Riviere, J.E. \& Sundlof, S.F. (2001) Chemical Residue in Tissues of Food Animals. In: Adams, H.R. (Eds.) Veterinary Pharmacology and Therapeutics, Vol. 8, pp. 1166-1174 (Blackwell Publishing Professional).

Samanidou, V.F., Tolika, E.P. \& Papadoyannis, I.N. (2008) Chromatographic Residue Analysis of Sulfonamides in Foodstuffs of Animal Origin. Separation and Purification Reviews, 37: 325-371.

Sambyal, D.S. \& Baxi, K.K. (1980) Bacterial flora of wild bird in Ludhiana (Punjab). Zentraibl Veterinaermed, 27: 165-168.

Seyed, Z., Mirhosseini, Alireza, S., Mahmoud, S., Mohammad, C., Sadeghi, A.A. \& Pourseify, R. (2010) Detection of Clostridium sp. and its Relation to Different Ages and Gastrointestinal Segments as Measured by Molecular Analysis of 16S rRNA Genes. Brazilian Archives in Biology and technology, 53: Curitiba Jan/Feb.

Sorum, H. \& Sunde, M. (2001) Resistance to antibiotics in the normal flora of animals. Veterinary Research, 32: 227-241.

Su-Ching, Y., Mei-Chu, Y., Yee-Hua, L., Jiun-Ling, W. (2016) Antibiotic Residues in Meat and Eggs in Taiwan: A Local Surveillance. British Journal of Medicine \& Medical Research, 12: 1-6. Article no.BJMMR.21922 ISSN: 2231-0614, NLM ID: 101570965 
Tatsadjieu, L.N., Tanedjeu, K.S. \& Mbofung, C.M.F. (2009) Impact de l'utilisation des antibiotiques sur la sensibilité des bactéries pathogènes de poules dans la ville de Ngaoundéré. Cameroon Journal of Experimental Biology, 5: 52-61.

The Council of the European Communities. (1990) Council Regulation (EEC) No.2377/90. Official Journal of the European Communities, L 224/P: 1-8.

Threlfall, E.J. (2002) Antimicrobial Drug Resistance in Salmonella: Problems and perspectives in food and water borne infections. FEMS Microbiology Reviews, 26: 141-148.

Tollefson, L. \& Miller, M.A. (2000) Antibiotic use in food animals: controlling the human health impact. Journal of AOAC International, 83: 245-256.

Turkson, P.K. (2008) Use of drugs and antibiotics in Ghana. Ghana Journal of Agric. Science, 41: 23-33.

USDA. (2009) The transformation of U.S. livestock agricultural scale, efficiency and risks. United States Department of Agriculture, 35.

WHO. (2003) Impacts of antimicrobial growth promoter termination in Denmark. The WHO international review panel's evaluation of the termination of the use of Antibiotic growth promoters in Denmark.

WHO. Antimicrobial resistance: global report on surveillance. Geneva: WHO Press; 2014. WHO.2013. Antimicrobial resistance, Fact sheet NN194

WHO. (2000) Overcoming Antibiotic resistance. WHO, 2000. 
Wongtavatchai, J., McLean, J.G., Ramos, F. \& Arnold, D. (2004) CHLORAMPHENICOL. WHO Food Additives Series, 53.

Woodward, K.N. (1993) Antibiotics and drugs uses in food production. Encyclopedia of Food Science, Food Technology and Nutrition, 249. 


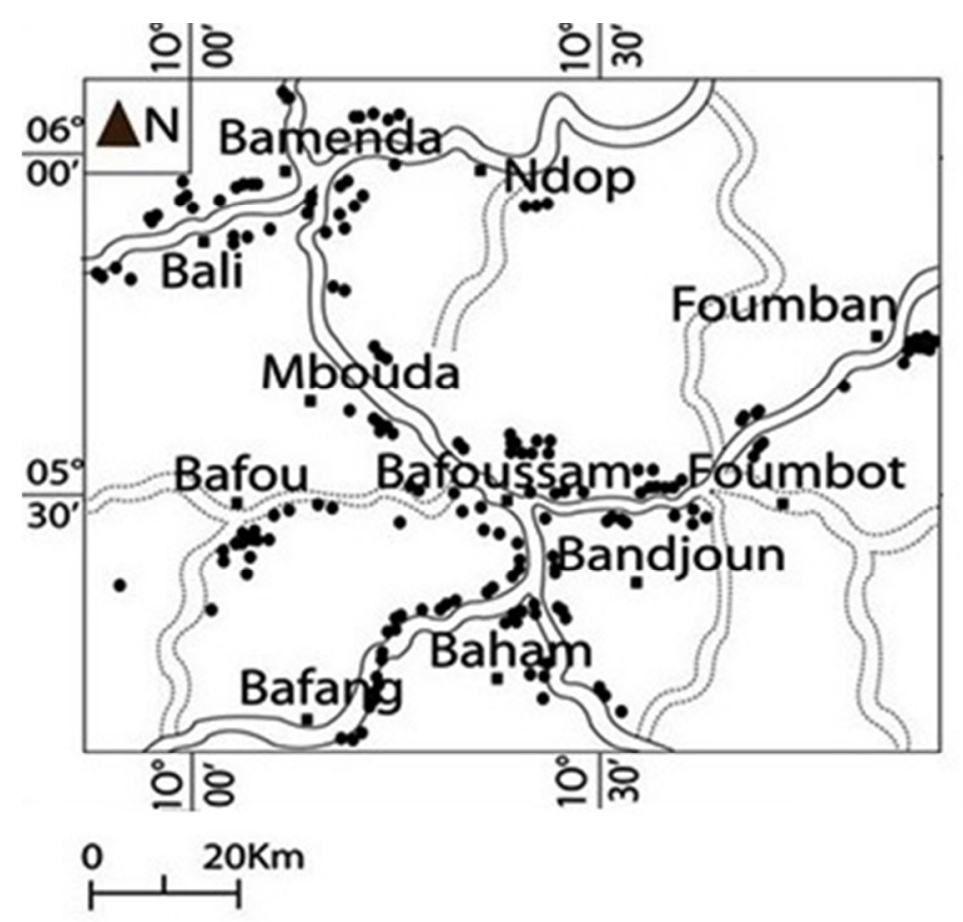

Figure: Georeference of investigated poultry farms in the Western Highlands of Cameroon. The georeference of each poultry farms was collected by the use of a Global Positioning System (GPS) receiver (GPSmap $76 \mathrm{CSx}$, Garmin). Each point spot $(\bullet)$ represents a poultry farm. Each square spot $(\mathbf{\bullet})$ represents a town. The

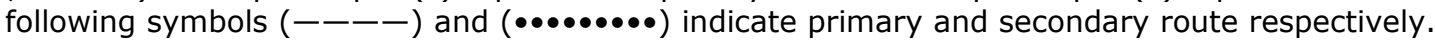
$98 \times 92 \mathrm{~mm}(96 \times 96$ DPI $)$ 
Table 1: Percentage of poultry farmers whom have received an appropriate training, are regularly medically examined and their education levelEducational status of staff of farms*

\begin{tabular}{|c|c|}
\hline Factors & Frequency $(n=131)$ \\
\hline \multicolumn{2}{|c|}{ Education level } \\
\hline Illiterate & $0(0)$ \\
\hline Basic Education & $20(15)$ \\
\hline Secondary/Vocational & $90(68)$ \\
\hline Tertiary & $20(15)$ \\
\hline No answer & $1(1)$ \\
\hline \multicolumn{2}{|c|}{ Training on poultry farming } \\
\hline Trained & $70(53)$ \\
\hline Untrained & $61(47)$ \\
\hline \multicolumn{2}{|c|}{ Medical examination } \\
\hline Medically examined & $15(11)$ \\
\hline Medically unexamined & $116(89)$ \\
\hline
\end{tabular}

*Percentages are in parenthesis 
Table 2: Knowledge of farmers on withdrawal period and it application as well as the rationale of usage and the factors they based on to select antibiotics Antibiotic usage and handling*

\begin{tabular}{|c|c|}
\hline Factors & Frequency $(n=131)$ \\
\hline \multicolumn{2}{|c|}{ Rationale for usage } \\
\hline In disease outbreak & $40(31)$ \\
\hline Prophylactic use & $05(4)$ \\
\hline Prophylactic and curative & $86(66)$ \\
\hline \multicolumn{2}{|c|}{ Reasons for choice } \\
\hline+2 & $117(89)$ \\
\hline Availability & $96(73)$ \\
\hline Potency & $26(20)$ \\
\hline Veterinary prescription & $24(20)$ \\
\hline Farmer prescription & $98(80)$ \\
\hline Cost & $117(89)$ \\
\hline \multicolumn{2}{|c|}{ Knowledge and respect of withdrawal period } \\
\hline Aware of withdrawal period & $61(46.6)$ \\
\hline Respect of withdrawal & $55(42.0)$ \\
\hline $\begin{array}{l}\text { Sales of products within antibiotic withdrawal } \\
\text { period }\end{array}$ & $65(49.6)$ \\
\hline $\begin{array}{l}\text { No sales of produce within antibiotic } \\
\text { withdrawal period for eating }\end{array}$ & $55(42.0)$ \\
\hline Aware of withdrawal period & $61(46.6)$ \\
\hline Respect of withdrawal & $55(42.0)$ \\
\hline
\end{tabular}

*Percentages are in parenthesis 
Table 3: Percentage of antimicrobials used in investigated farms in the Western Highlands of Cameroon. The informations were collected by the use of a well structure questionnaire written in English and French Antimierobials used in investigated farms

\begin{tabular}{|c|c|c|c|c|}
\hline Antimicrobials used & Active ingredients & Withdrawal period & Total & $\begin{array}{l}\text { Percentage } \\
(\mathrm{N}=131)\end{array}$ \\
\hline Hipralona Nor-S & Norfloxacin $200 \mathrm{mg}$ & $\mathrm{NI}^{*}$ & 49 & $37.4 \%$ \\
\hline \multicolumn{5}{|l|}{ Enrofloxacin \& } \\
\hline Bromhexin $\mathrm{HCl}$ solution & Enrofloxacin 200mg & NI & 35 & $26.7 \%$ \\
\hline Amprolium & NI & NI & 3 & $2.29 \%$ \\
\hline Norfloxan $20 \%$ & Norfloxacin $200 \mathrm{mg}$ & 4 days & 40 & $30.53 \%$ \\
\hline \multirow[t]{2}{*}{ Anticoc super } & Sodium sulfadimerazin $860 \mathrm{~g}$ & $\mathrm{NI}$ & 18 & $13.74 \%$ \\
\hline & and diaveridin $105 \mathrm{~g}$ & & & \\
\hline & & 7 days for meat and $\mathrm{dc}$ & & \\
\hline Enroveto - 20 & Enrofloxacin 200mg & use in layers & 38 & $29.00 \%$ \\
\hline Oxyveto $-50 \mathrm{~S}$ & Oxytetraxyclin 500mg & 7 days & 121 & $93 \%$ \\
\hline \multirow[t]{2}{*}{ Vetacox S } & Sodium Sulfadimidin $80 \mathrm{~g} \&$ diaveridin $8 \mathrm{~g}$ & 14 days & 84 & $64 \%$ \\
\hline & Oxytetraxyclin HCL 50mg & & $\bar{c}$ & \\
\hline \multirow[t]{2}{*}{ TCN powder } & Chloramphenicol 50mg & 21 days & 88 & $67.18 \%$ \\
\hline & Neomycin sulphate $25 \mathrm{mg}$ & & & \\
\hline & Trimethoprim $4 \mathrm{~g}$ & & & 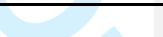 \\
\hline T.T.S & sodium sulfadiazine $18.88 \mathrm{~g}$ & 12days & 20 & $15.3 \%$ \\
\hline BioPHA-FF & Flumequin $40 \mathrm{~g}$ and Furaltadon $45 \mathrm{~g}$ & $\mathrm{NI}$ & 64 & $49 \%$ \\
\hline Doxylin 200 wsp & Doxyciclin 200mg & 7 days & 65 & $49.62 \%$ \\
\hline Vet - colis 200 wsp & Colistin Sulphate $200 \mathrm{mg}$ & 7 days & 53 & $40.5 \%$ \\
\hline
\end{tabular}

Formatted: No underline

Formatted: Font: Not Bold 


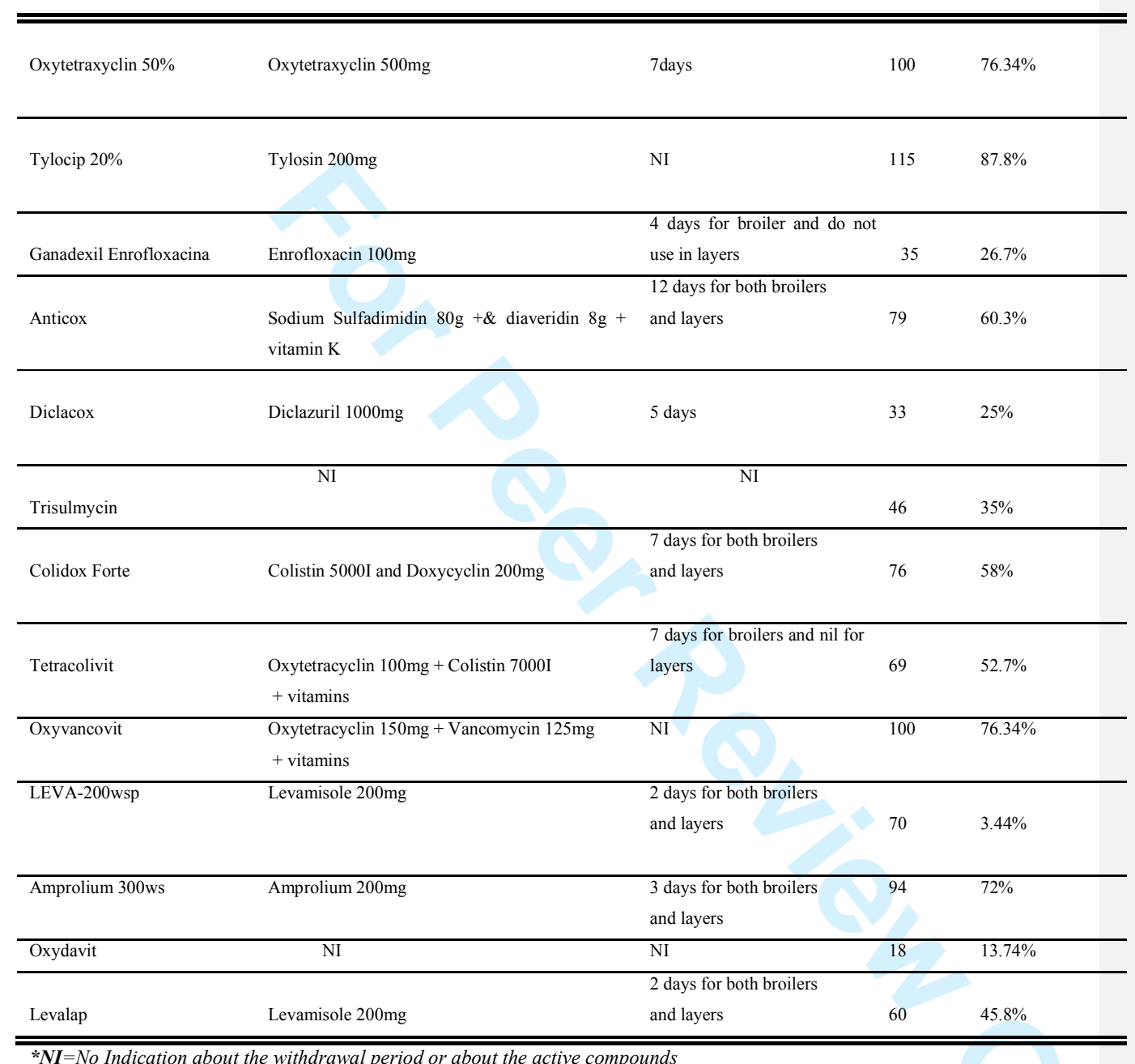

*NI=No Indication about the withdrawal period or about the active compounds

-


Table 4: Concentration of Chloramphenicol, Tetracyclin and Vancomycin in edible tissues as quantified by HPLC with comparison to MRL (Maximum Residue Limits) defined by the European Union (EU) regulation commission No 37/2010 Concentration of antibiotics residues in various tissues

\begin{tabular}{|c|c|c|c|c|}
\hline Antibiotic & Sample & $\begin{array}{c}\text { Residues level } \\
\qquad(\mu \mathrm{g} / \mathrm{g})\end{array}$ & $\begin{array}{l}\text { MRLs* } \\
(\mu \mathrm{g} / \mathrm{g})\end{array}$ & Judgment \\
\hline \multirow{7}{*}{ Chloramphenicol } & muscle & $1 . \underline{4} 366 \pm 0.3216^{\mathrm{a}}$ & \multirow{3}{*}{ Prohibited substance } & \multirow{7}{*}{ Rejected } \\
\hline & gizzards & Not detectable $^{b}$ & & \\
\hline & heart & $\begin{array}{c}\text { Not detectable } 0.000 \\
\pm 0.000^{\mathrm{b}}\end{array}$ & & \\
\hline & kidney & $\begin{array}{c}\text { Not detectable } 0.000 \\
\pm 0.00 \theta^{-}\end{array}$ & & \\
\hline & liver & $\begin{array}{c}\text { Not detectable } 0.000 \\
\pm 0.000^{b}\end{array}$ & & \\
\hline & Egg white & $\begin{array}{c}\frac{\text { Not detectable }}{} \theta .00 \theta \\
\pm 0.00 \theta^{\natural}\end{array}$ & & \\
\hline & Egg yolk & $\begin{array}{c}\text { Not detectable } 0.000 \\
\pm 0.000^{\mathrm{b}}\end{array}$ & & \\
\hline \multirow{7}{*}{ Tetracyclin } & muscle & $62 . \underline{4} 380 \pm 15 . \underline{3} 261^{b}$ & 0.1 & Rejected \\
\hline & gizzards & $21.3290 \pm 4 . \underline{3} 278^{\mathrm{c}}$ & ND** & Rejected \\
\hline & heart & $\underline{16} 15.950 \pm 9.7629^{\mathrm{c}}$ & ND & Rejected \\
\hline & kidney & $8.9780 \pm 4.9878^{\mathrm{d}}$ & 0.6 & Rejected \\
\hline & liver & $150.030 \pm 30.8780^{\mathrm{a}}$ & 0.3 & Rejected \\
\hline & Egg white & $\begin{array}{c}\frac{\text { Not detectable } 0.000}{ \pm 0.000^{\mathrm{e}}} \\
\end{array}$ & 0.2 & Pass \\
\hline & Egg yolk & $\begin{array}{c}\text { Not detectable } 0.000 \\
\pm 0.000^{\mathrm{e}}\end{array}$ & 0.2 & Pass \\
\hline \multirow{4}{*}{ Vancomycin } & muscle & $\begin{array}{c}\text { Not detectable } 0.000 \\
\pm 0.000^{-4}\end{array}$ & \multirow{4}{*}{ (MRL cannot be established) } & \multirow{4}{*}{ Rejected } \\
\hline & gizzards & $\begin{array}{c}\text { Not detectable } \theta .00 \theta \\
\pm 0.00 \theta^{-4}\end{array}$ & & \\
\hline & heart & $\begin{array}{c}\text { Not detectable } \theta .00 \theta \\
\pm 0.00 \theta^{-2}\end{array}$ & & \\
\hline & kidney & Not detectable 0.000 & & \\
\hline
\end{tabular}

Formatted: Font: Not Bold
Formatted: Font: Not Bold
Formatted: Font: Not Bold
Formatted: Font: Not Bold, Not Italic




\section{Page 33 of 37}

2

3

4

5

6

7

8

9

10

11

12

13

14

15

16

17

18

19

20

21

22

23

24

25

26

27

28

29

30

31

32

33

34

35

36

37

38

39

40

41

42

43

44

45

46

47

48

49

50

51

52

53

54

55

56

57

58

59

60

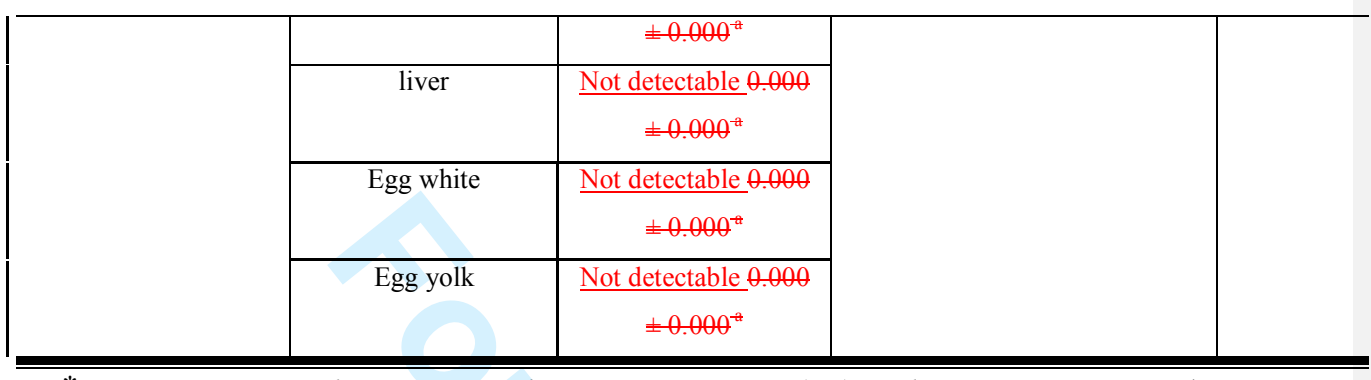

*MRLs: Maximum Residue Limits, according to European Union (EU) regulation commission No 37/2010 [45]

**ND: Not defined; Number having the same letter are not significantly different $(p>0.05)$. 
Table 5: Percentage of pathogenic strains isolated from chicken faeces using selective and semiselective growth media and identified by the use of API 20E, API Staph and API 20NE systems Pathogenic strains isolated and identified

\begin{tabular}{l|c}
\hline \hline Name of strains & Percentage (\%) of isolates (N= 28) \\
\hline \hline Clostridium sp. & 7.14 \\
\hline Escherichia vulneris & 10.71 \\
\hline Proteus vulgaris & 7.14 \\
\hline Proteus mirabilis & 10.74 \\
\hline Providencia rettgevi & 10.71 \\
\hline Pseudomonas aeruginosa & 3.57 \\
\hline Staphylococcus sciuri & 7.14 \\
\hline Staphylococcus epidermidis & 7.14 \\
\hline Salmonella sp. & 17.86 \\
\hline Listeria sp. & 10.71 \\
\hline Shigella sp. & 7.14 \\
\hline \hline
\end{tabular}


Table 6: Percentage of antibiotic susceptibility of pathogenic strains isolated from chicken faeces as interpreted according to the FEEDAP (Panel on Additives and Products or substances used in Animal Feed) document of the EFSA (European Food Safety Authority) and the standards set by the CLSI (Clinical Laboratory Standards Institute), formerly National Committee for Clinical Laboratory Standards Resistance percentage of pathogenic bacteria isolated from poultry

Resistant percentage of isolated pathogenic strains

\begin{tabular}{|c|c|c|c|c|c|c|c|c|c|c|c|}
\hline pathogenic strains & GEN & KAN & AMC & AMP & ENR & ERY & XNL & CHL & SXT & TET & VAN \\
\hline Clostridium sp. & 0 & 100 & 100 & $\mathrm{ND}^{*}$ & 100 & 0 & 100 & 0 & 0 & 100 & 0 \\
\hline Escherichia vulneris & 100 & 0 & 0 & 100 & 100 & 100 & 0 & 0 & 0 & 0 & 0 \\
\hline Proteus vulgaris & 0 & 0 & 100 & 100 & 0 & 0 & 0 & 0 & 100 & 100 & 100 \\
\hline Proteus mirabilis & 0 & 0 & 0 & 0 & 0 & 100 & 0 & 0 & 100 & 0 & 100 \\
\hline Providencia rettgevi & 100 & 0 & 0 & 0 & 0 & 100 & 100 & 100 & 0 & 100 & 100 \\
\hline $\begin{array}{l}\text { Pseudomonas } \\
\text { aeruginosa }\end{array}$ & 0 & 100 & 100 & 100 & 0 & 100 & 0 & 0 & 100 & 100 & 0 \\
\hline Staphylococcus sciuri & 100 & 100 & 100 & 100 & 100 & 100 & 0 & 100 & 0 & 0 & 100 \\
\hline $\begin{array}{l}\text { Staphylococcus } \\
\text { epidermidis }\end{array}$ & 100 & 100 & 100 & 100 & 100 & 100 & 0 & 0 & 0 & 0 & 100 \\
\hline Salmonella sp. & 100 & 100 & 100 & 100 & 100 & 100 & 100 & 100 & 100 & 100 & 100 \\
\hline Listeria sp. & 100 & 0 & 0 & 0 & 0 & 100 & 100 & 0 & 0 & 100 & 0 \\
\hline Shigella sp. & 0 & 0 & 100 & 0 & 0 & 100 & 100 & 100 & 0 & 100 & 100 \\
\hline $\begin{array}{l}\text { Percentage of resistant } \\
\text { isolates/antibiotics }\end{array}$ & $54.56 \%$ & $45.46 \%$ & $63.64 \%$ & $54.55 \%$ & $45.46 \%$ & $81.82 \%$ & $45.46 \%$ & $36.36 \%$ & $36.36 \%$ & $63.64 \%$ & $63.64 \%$ \\
\hline
\end{tabular}

"ND: Not Defined; GEN= Gentamycin; KAN= Kanamycin; $\quad$ AMC=Amoxicillin-clavulanic acid; AMP= Ampicilin; ENR=Enrofloxacin; $\quad$ ERY=Erythromycin; $\quad \mathbf{X N L}=\quad$ Ceftiofur; $\quad \mathbf{C H L}=$ Chloramphenicol; $\quad \mathbf{S X T}=$ Trimethoprimsulfamethoxazole; TET $=$ Tetracycline; VAN $=$ Vancomycin 


\author{
UNIVERSITE DE DSCHANG \\ UNIVERSITY OF DSCHANG \\ $* * * * * * * * * * *$ \\ FACULTE DES SCIENCES \\ FACULTY OF SCIENCE \\ $* * * * * * * * * * *$ \\ DEPARTEMENT DE BIOCHIMIE \\ DEPARTMENT OF BIOCHEMISTRY \\ $* * * * * * * * *$ \\ BP: 67 Dschang Cameroun \\ Tel: (237) 33451735
}

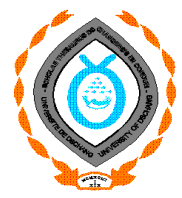

REPUBLIQUE DU CAMEROUN Paix-Travail-Patrie

\section{REPUBLIC OF CAMEROON}

Peace-Work-Fatherland

ACADEMIC INQUIRY FOR A DOCTORAL THESIS/PhD

\begin{tabular}{|c|c|c|c|c|}
\hline \multirow{2}{*}{ IDENTIFICATION } & 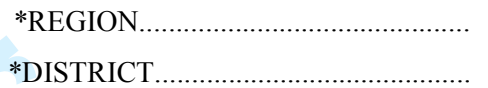 & 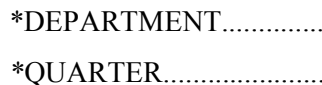 & $\ldots \ldots$ & \\
\hline & 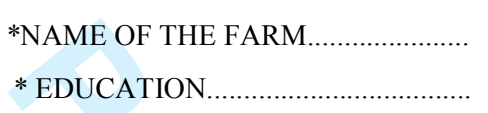 & *TYPE OF OPERATION & $\begin{array}{l}\text { Poultry } \\
\text { Mixed Farming }\end{array}$ & $\square$ \\
\hline
\end{tabular}

-Dear brother / sister:

-This questionnaire was developed in order to collect data on the use of antibiotics in poultry farms.

- On the last page, you can add information and comments that you consider useful in the practice of antibiotic therapy in this type of farming.

- With your valuable cooperation. Please accept dear brother, / sister, best regards.

1. What is the importance of poultry activity in your life (check one)?

- Main activity [ ]

- Secondary activity [ ]

2. What kind of speculation you generally follow?

- Broiler [..... $\quad$ - Local chicks [.....] - Laying Hen [.....] - started [.....] - Broiler- Laying Hen [.....]

3. What is the herd size of animals in the current production?

4. What are the main pathologies encountered?

\section{Major Diseases}

\begin{tabular}{|l|l|l|l|l|l|}
\hline Speculation & Digestive & Breathing & Nervous & Locomotor App. & Nutritional \\
\hline Broiler & & & & & \\
\hline Laying Hen & & & & & \\
\hline Local chicks & & & & & \\
\hline
\end{tabular}

5. Which antibiotic molecules do you use?

Furaltadon [......] Flumequin [......] Amoxicillin [......] Céfixime [......] Oxytetracyclin [....... Streptomycin [.......]

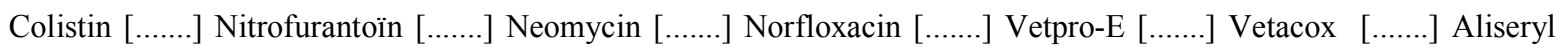
[......] Fumesol [......] Erythromycin [......] Penicillin [......] Ampicilin [......] Tetracyclin [....... T.T.S [.......] Chloramphenicol [......] Doxycyclin [......] Ciprofloxacin [.......] Bactrim (Cotrimodazole) [.......] Sulphamides [......] Trimethoprim [......] Flagyl (Metronidazole) [.......] Vermox (Mebendazole) [.......] Sulfadiazin [.......] Tylosin [.......] Other 
6. For what purpose do you use antibiotics?

- Curative (in disease outbreak) [ ] $\quad$ - Prophylactic [ ] $\quad$ - Prophylactic and Curative [ ]

7. How do you choose antibiotics to be given to animals?

Personal selection [ ] - Cost [ ] - Availability [ ] - Efficacy (Potency) [ ] - Veterinary prescription [ ] - Drug dealer prescription [ ] - Other

8. Where do you purchase the antibiotics?

-Veterinary Pharmacy [ ] - Farm Pharmacy [ ] _ - Local market [ ] - Other

9. Who generally administer the antibiotic?

- Yourself [ ] - The Veterinary doctor [ ]

- Other

10. How do you administer the antibiotic?
- Water [ ]
- Food [ ] - Gavage [ ]
- Other

11. When do you stop the antibiotic treatment?

- Disappearance of symptoms (even before the end of the specified time)

- End of the recommended amount of the drug

12. Practically, how do you establish the dosage?

- Count the animals [ ] - Estimation [ ] - Weighing (with scale) [ ] - Following Sheet [ ] - Estimation [ ] -Vet instructions [ ]

13. What is the frequency of administration of antibiotics by production cycle?

- 1 time [ ] -2 times [ ] -3 times [ ] - continuously [ ] - Depending on outbreak of diseases [ ] - Other ........../

14. What quantity of antibiotics do you use per production cycle of 100 chickens?

$-50 \mathrm{~g}$ [ ] - 100g [ ] - 150g [ ] - 200g [ ] - 250g [ ] - 300g [ ] - 350g [ ] - 400g [ ] - 450g [ ] - 500g [ ] - Other........./

15. Do you know the concept of « withdrawal period»?

- Yes []

16. If yes, do you observe these deadlines?

- Yes [ ]

$$
\text { - No [ ] }
$$

17. What is the duration of the " withdrawal period» you observe?

- 0 day [ ] - 2 days [ ] - 4 days [ ] - 6 days [ ] - 7 days [ ] - 8 days [ ] - 10 days [ ] - 12 days [ ] - 14 days [ ]

- 15 days [ ] - 16 days [ ] - 17 days [ ] - 18 days [ ] - 19 days [ ] - 20 days [ ] - Other .....

18. Do you sale the animals during this withdrawal period?

- Yes [ ]

- No [ ]

19. Have you received training on poultry farming?

- Yes [ ]

20. Are you often medically examined?

- Yes []

- No [ ]

\section{INFORMATION AND/OR NOTES}

Thanks for your collaboration and time spent completing this questionnaire 